\title{
O desafio de implantar um plano de cultura para a cidade do Rio de Janeiro' ${ }^{1}$
}

\section{El reto de implementar un plan cultural para la ciudad de Río de Janeiro}

\author{
The challenge of implementing a culture plan \\ for the city of Rio de Janeiro
}

\author{
Ana Lúcia Pardo²
}

\section{Palavras-chave: \\ Cidade \\ Cidadania \\ Plano de cultura \\ Política pública \\ Estado \\ Sociedade civil}

\section{Resumo:}

Este artigo propõe refletir sobre o processo de trabalho de construção do Plano Municipal de Cultura do Rio de Janeiro, da qual fiz parte como consultora da sua primeira etapa. Um plano decenal, cujo principal desafio é ultrapassar as ações pontuais propondo uma política de Estado. Porém, a continuidade desse processo foi interrompida, tornando-se a própria implementação do PMC-RJ um dos grandes desafios, dentre outros que se impõem: Como fazer um plano que espelhe as carências e potências dessa cidade? Como garantir o pleno exercício dos direitos culturais dos atores desse processo? Como corrigir desigualdades e concentrações? Como democratizar o acesso e a participação? Proponho discutir questões que devem estar nas bases de implantação de uma política cultural, dentro de um conceito de cultura cidadã, desde o qual construir cidade é construir cidadania para a cidade.

1 Texto recebido em 2410/2019 e aceito para publicação em 28/10/2019.

2 Ana Lúcia Ribeiro Pardo. Pós-doutoranda e professora do Programa de Pós-Graduação em Cultura e Territorialidades (PPCULT-UFF), bolsista de pesquisa da (CAPES/PNPD), Brasil. Doutora e mestre em Políticas Públicas e Formação Humana (PPFH/UERJ). Contato: anapardo.teatralidade@gmail.com 


\section{Resumen:}

Este artículo propone reflexionar sobre el proceso de construcción del Plan de Cultura Municipal de Río de Janeiro, del cual fui parte de su primera etapa. Un plan decenal, cuyo principal desafío es superar las acciones puntuales que proponen una política de Estado. Sin embargo, la continuidad de este proceso se interrumpió, convirtiéndose en la propia implementación del PMC-RJ uno de los grandes retos, entre otros que se requieren: ¿Cómo hacer un plan que refleje las necesidades y poderes de esta ciudad? ¿Cómo podemos garantizar el pleno ejercicio de los derechos culturales de los actores de este proceso? ¿Cómo corregir las desigualdades y concentraciones? ¿Cómo democratizar el acceso y la participación? Propongo debatir cuestiones que deben basarse en la aplicación de una política cultural, dentro de un concepto de cultura ciudadana, ya que construir una ciudad es construir la ciudadanía para la ciudad.
Palabras clave:

Ciudad

Ciudadania

Plan cultural

Política pública

Estado

Sociedad civil

\section{Keywords:}

City

Citizanship

Culture plan

Public policy

State

Civil society

\section{Abstract:}

This article proposes to reflect on the construction work process of the Municipal Culture Plan of Rio de Janeiro, of which I was a part of its first stage. A decenal plan, whose main challenge is to overcome the one-off actions proposing a state policy. However, the continuity of this process was interrupted, becoming the very implementation of the PMC-RJ one of the great challenges, among others that are required: How to make a plan that reflects the needs and powers of this city? How can we ensure the full exercise of the cultural rights of the actors of this process? How to correct inequalities and concentrations? How to democratize access and participation? I propose to discuss issues that should be on the basis of the implementation of a cultural policy, within a concept of citizen culture, since which to build a city is to build citizenship for the city. 


\section{O desafio de implantar um plano de cultura para a cidade do Rio de Janeiro}

Ao vivenciarmos a primeira etapa do trabalho de construção do Plano Municipal de Cultura do Rio de Janeiro (PMC$-R J)$, fruto de um pacto federativo e do convênio assinado com o governo federal, como significa um elemento constitutivo fundamental do Sistema Nacional de Cultura, torna-se imprescindível e urgente discutir quais serão as diretrizes apontadas no planejamento dos próximos dez anos e em que bases será consolidado. Mais ainda, qual é a garantia de continuidade e retomada deste trabalho para sua efetiva implementação, uma vez que o plano se encontra neste momento paralisado aguardando uma definição da nova gestão da Secretaria Municipal de Cultura da cidade? Este artigo pretende contribuir no sentido de problematizar e levantar questões, a partir de referenciais teóricos, para se analisar o processo de construção de uma política pública municipal a partir da implantação do Plano de Cultura da Cidade do Rio de Janeiro, dentro do conceito de uma Cultura cidadã.

É possível perceber que a sociedade clama por uma política pública de Cultura que tenha continuidade, uma política de Estado, para além de uma gestão de governo, fundamentada, construída, proposta e formulada em conjunto com os diversos setores da sociedade. Mas, para isso de fato acontecer, é fundamental que a política esteja referenciada em diagnósticos, levantamentos, pesquisas, mapeamentos, considerando os anseios e as necessidades de cidadãos e cidadãs que conferem vida, movimento e expressão à cidade.

Em resposta a esta inquietação, a cidade do Rio de Janeiro iniciou em 2012 o seu processo de construção do Plano Municipal de Cultura, tendo que assumir pela frente como principal desafio desta política de Estado, o de ultrapassar ações pontuais e eventuais, traçando diretrizes e metas para os próximos dez anos. Isso supõe a descentralização de recursos direcionados às áreas desassistidas das periferias da cidade, além do fomento e apoio às diferentes linguagens artísticas, à valorização, salvaguarda, proteção e manutenção das comunidades tradicionais, da memória e das identidades locais da cidade do Rio de Janeiro.

No Documento Base da Prefeitura, o planejamento proposto para a formulação de um Plano Municipal de Cultura do Rio de Janeiro pressupõe, necessariamente, um amplo diálogo com a população carioca. Ainda que possa apontar caminhos, partindo de diagnósticos e análises acerca de programas e projetos executados nos últimos anos, é preciso reconhecer o acúmulo cultural dos seus diferentes atores, apostando numa construção coletiva. Para isso, será importante reafirmar as identidades locais como único instrumento válido para a emancipação humana dentro de uma cidadania democrática e plural.

A formulação do PMC-RJ precisará espelhar a diversidade cultural da cidade, suas potencialidades artísticas, seu poder de invenção, criação e renovação, de modo a propor políticas transversais da Cultura com as áreas de Educação, Comunicação, Turismo, Meio Ambiente, Ciência e Tecnologia, Habitação, Saúde etc. Isso em respeito à cidade do Rio de Janeiro, daquilo que representa e que ainda pode ser, do que anseia e merece ser, da força de seu povo que trabalha, luta, constrói e faz dela uma cidade que ficou conhecida como maravilhosa. Esta cidade que é a primeira do mundo a receber o título da UNESCO de Patrimônio Mundial como Paisagem Cultural Urbana. 
Por isso, se fez necessário e urgente um Plano de Cultura, para se pensar nos caminhos futuros a partir das carências e potências da cidade, que pactue com a população e esteja alinhado dentro de uma visão sistêmica com o poder público estadual e federal. Uma política cultural, portanto, que dê condições para deixar florescer a cidade e seus cidadãos e que dialogue com gestores, especialistas e agentes de outras áreas.

Isso significa pensar a especificidade de cada segmento e, ao mesmo tempo, criar políticas conjuntas, pactuadas, com espaço para o individual e o coletivo, o local e o global, o territorial, o nacional e o mundial, o que implica colocar a Cultura na centralidade do governo, com suas práticas, políticas e estudos acerca da sociedade contemporânea. Nessa direção, a Secretaria Municipal de Cultura do Rio de Janeiro, através de um convênio firmado com o Ministério da Cultura e a Universidade Federal da Bahia, deu início, em fevereiro de 2012, ao processo de trabalho com vistas à elaboração de um Plano Municipal de Cultura para a cidade.

Inicialmente, foram feitos mapeamentos, diagnósticos e levantamento de informações sobre os equipamentos, serviços e condições de produção e o acesso cultural, bem como, o alinhamento às metas do Plano Nacional de Cultura. A equipe partiu, num primeiro momento, para o diálogo, a escuta e a discussão de prioridades com os agentes culturais e a sociedade como um todo. Essa etapa de diálogo e discussão com a sociedade exigiu a convocação de representantes dos segmentos artístico-culturais para participarem de uma série de 12 encontros setoriais de Dança, Teatro, Circo, Música, Artes Visuais, Artes Urbanas, Artes Populares, Audiovisual, Livro e Leitura, Museus, Patrimônio e Memória, Arquivo, bem como, das Unidades de Polícia Pacificadora - UPP Social.
Para a elaboração do Plano de Cultura do Rio, os dados foram sistematizados tomando por base os seguintes documentos: os 12 Encontros Setoriais; as propostas levantadas na I Conferência Municipal de Cultura, realizada em 2009; as metas definidas para a área de Cultura no Plano Diretor da Cidade; as metas da Lei Orgânica do Município do Rio; o Plano Estratégico da Prefeitura do Rio para 2013/2016 e o alinhamento às Metas do Plano Nacional de Cultura.

Durante esse processo de construção do PMC-RJ, buscamos apresentar uma síntese com os principais problemas e os obstáculos ao desenvolvimento cultural da cidade. Um diagnóstico cultural que nos trouxe como resultado o que chamamos de uma Radiografia de Fragilidades (A), tais como: A1. Ausência de dados, mapeamentos e pesquisas em torno das manifestações culturais, da distribuição dos bens culturais e dos hábitos de consumo cultural na cidade do Rio de Janeiro; A2. Carência de escritórios de apoio e formação de técnicos, artistas e gestores; A3. Dificuldade de acesso e apoio, principalmente de novos agentes culturais aos programas de fomento; A4. Concentração de equipamentos culturais em determinadas regiões obrigando também a reestruturá-los e a ampliar o seu atendimento; A5. Falta de percepção por parte da população da potencialidade da Cultura da cidade. Faltava à cidade a sistematização de informações que explicitem hábitos e manifestações culturais, essa era uma das metas elencadas no Plano Estratégico da Cidade 2013-2016.

Até o ano 2013, a cadeia da economia da Cultura, a quantidade de equipamentos culturais e as atividades e demandas da área precisavam estar mapeadas para, assim, embasar a elaboração de políticas para os setores, conforme; A6. Carência de espaços públicos de formação para técnicos, artistas, produtores e ges- 
tores culturais. E apresentam as seguintes Diretrizes (B): B1. Necessidade de revisão da Lei Orgânica do Município; B2. Revisão das leis tributárias; B3. Preservação de acervos; B4. Assegurar a integração entre as secretarias na promoção de projetos de cunho cultural; B5. Promover políticas transversais da Cultura com outras áreas.

Essa etapa, que compreendeu a realização desses doze encontros setoriais, foi fundamental uma vez que possibilitou promover o diálogo e uma escuta mais apurada com os agentes culturais. Os resultados obtidos nos encontros deram maior consistência e insumos para o diagnóstico geral e específico acerca dos problemas, vocações e potencialidades da Cultura nas diferentes regiões e territórios da cidade.

Conforme o levantamento, a cidade do Rio possuía naquele momento 18 escolas técnicas, 6 delas públicas, para a formação de artistas nas áreas de Dança, Música, Circo e Artes Dramáticas. Naquele momento, não havia sido encontrada nenhuma escola técnica voltada para a capacitação e a formação de gestores culturais. Uma iniciativa encontrada nesse sentido, seria o Programa de Capacitação RioFilme/Senai 2012 - para profissionais e estudantes do setor Audiovisual fluminense, de acordo com a categoria de Fragilidades (A) - aqui retomada: A7. Necessidade de capacitação técnica para gestores que administram espaços públicos da rede de equipamentos municipais de Cultura. Os servidores da Secretaria Municipal de Cultura começaram a ser capacitados a partir de 2011 e, com a previsão de serem capacitados 164 servidores até o final de 2012. E A8. Carência de escritórios de apoio para auxiliar na confecção de projetos culturais no município.

A Secretaria de Estado de Cultura criou em 2008 o Escritório de Apoio à Produção Cultural com atuação voltada para a qualificação dos projetos apresentados aos editais da Secretaria de Estado de Cultura do Rio de Janeiro e do Ministério da Cultura. O Escritório foi criado em parceria com o SEBRAE e o MinC e foi desativado em 2012. Foram atendidos, nesse período, 4.232 projetos da cidade do Rio. No âmbito municipal, identificamos o convênio, criado em 2010 com o SEBRAE e a SMC-RJ, para capacitar gestores/produtores de instituições culturais localizadas no entorno de um dos equipamentos municipais (Centro de Artes Calouste Gulbenkian). Esse convênio, que se estendeu por três meses, capacitou 19 pessoas na elaboração de planos de negócio, 15 em projetos de captação de recursos e o escritório de modelação de projetos atendeu 66 pessoas. Ao avaliar a quantidade de pedidos pela criação de um escritório municipal de projetos, concluiu-se que essa necessidade ainda não havia sido sanada já que essa demanda havia sido apontada em todas as reuniões pelos diferentes setores.

$\mathrm{Na}$ sequência, as Fragilidades levantadas nesse diagnóstico cultural apontou ainda: A9. Percepção, por parte de produtores e artistas, sobre a dificuldade de acesso aos investimentos e financiamentos de fomentos públicos aos novos sujeitos criativos da Cultura. Identificou-se que nos editais municipais havia a necessidade de comprovação de 2 anos de experiência e nos editais estaduais 4 anos o que, automaticamente, afastaria o jovem e o novo produtor de acessar aos fomentos públicos. E também A10. Ausência de um programa permanente de Arte-educação para a formação de educadores, em especial, voltado para museus e centros culturais da cidade. Um programa permanente ainda não havia sido desenvolvido pela Secretaria Municipal de Cultura do Rio, mas no ano de 2012, a Secretaria ministrou 2 seminários e 2 cursos voltados ao tema da Arte-educação. Um dos seminários, que estava voltado principalmente 
aos professores, com palestras e debates sobre as ações de Arte- educação, contou com 1.420 participantes.

O segundo seminário, cujo tema tratou das Ações Educativas em Arte Contemporânea, se propôs a discutir possíveis abordagens e promover a reflexão acerca das questões que fundamentam as ações e as proposições educativas elaboradas em exposições de Arte Contemporânea. Esse seminário, realizado no período de 2 a 5 de outubro de 2012, pela Secretaria Municipal de Cultura da Cidade do Rio junto com o Centro Municipal de Arte Hélio Oiticica, teve um público total de 200 educadores ao longo de 4 encontros. Nos cursos, Encontro com Educadores -Arte Brasileira: Uma panorâmica, foram feitos 26 encontros com a capacitação de 870 educadores, cujo intuito era que os educadores levassem para a sala de aula o tema Arte Brasileira. Para tanto, foram aplicadas aulas teóricas associadas a laboratórios de Arte. Já no curso Arte Educação Inclusiva: A Arte na Inclusão de Pessoas com Deficiência Física, Intelectual e Sensorial, 360 educadores foram capacitados num total de 12 encontros.

Nesse levantamento, surgiram também outras questões como: A11. Insuficiência de espaços de apresentação e principalmente de poucos palcos adequados à Dança na cidade para o atendimento da demanda da produção. Existem atualmente 110 palcos na cidade onde 27 são municipais, 11 estaduais, 15 federais e 56 privados. Com a alavancada do número de produções fomentadas pelos editais, ocorrida naquele período, a quantidade de palcos vinha se mostrando insuficiente para atender a essa demanda.

No caso da Dança, soma-se a esse problema o fato de que somente 2 palcos são específicos para o setor, no caso, o Teatro Cacilda Becker e o Centro Coreo- gráfico, e os demais espaços são pouco adaptados às especificidades desse segmento. Dos 27 equipamentos municipais, apenas 4 são palcos apropriados à Dança. Ainda nesse campo de Fragilidades, foram apontadas: A11. Necessidade de reestruturação e revocacionamento dos equipamentos públicos de Cultura, no sentido de prepará-los para o recebimento das diferentes manifestações artísticas e A12. Falta de um programa de bolsas de pesquisa para artistas.

A Secretaria Municipal tinha uma bolsa de pesquisa patrocinada pela Fundação Rio Arte, a qual havia sido extinta, em 2006, com o fechamento da Fundação.

No que se refere aos editais, esta foi ainda uma fragilidade: A13. A política de fomento via editais não atende de forma universal a todos os segmentos artísticos, principalmente produtores e artistas das áreas distintas do eixo Centro- Zona Sul. O Edital de Apoio ao Teatro (FATE) existe na Prefeitura desde 2003, mas a partir de 2011 foram criados os Editais de Apoio à Música (FAM), à Dança (FADA), às Artes Visuais (PRÓ-ARTES VISUAIS) e ao Audiovisual (FAC).

Ao analisarmos os números dos editais dos anos de 2011 e 2012, constatamos que a maior parte dos projetos apoiados eram oriundos de produtoras sediadas na Zona Sul (AP2) e no Centro da cidade (AP1). Porém, esse dado isolado não explica a informação apontada pelos produtores em reuniões. Para a exatidão dessa informação, necessitaríamos de uma pesquisa mais aprofundada. Segundo informações coletadas com os analistas de alguns segmentos pesquisados, os projetos de produtores vindos da periferia precisavam de melhor formulação, aonde se concluiu a necessidade de um escritório de projetos para auxiliá-los na elaboração dos projetos a serem enviados aos editais de fomento. 
Mencionamos aqui os resultados, com o número de projetos aprovados e as Áreas de Planejamento (AP) procedentes, nos anos de 2011 e 2012: FATE 2011- 75 projetos apoiados - AP1- 16 AP2-55 AP31 AP4-3 AP5-0; FATE 2012 - 64 projetos apoiados - AP1-13 AP2- 45 AP3- 1 AP4- 5 AP5-0; FADA 2011- 31 projetos apoiados - AP1 - 7 AP2- 20 AP3 - 1 AP4-3 AP5-0; FADA 2012- 24 projetos apoiados - AP1 - 6 AP2- 13 AP3- 3 AP4-2 AP5 - 0; FAM 2011 - 24 projetos apoiados - AP1 -6 AP216 AP3- 2 AP4-0 AP5-0; FAM 2012 - 19 projetos apoiados - AP1- 3 AP2 -14 AP3-
1 AP4- 1 AP5 - 0; PRÓ- ARTES VISUAIS 2011-28 projetos apoiados - AP1 - 6 AP220 AP3- 1 AP4-1 AP5- 0; PRÓ- ARTES VISUAIS 2012 - 29 projetos apoiados - AP1 - 9 AP2 - 16 AP3- 3 AP4 - 0 AP5. O Mapa das APs, disponibilizado pela prefeitura, pode ser visto abaixo.

Cumpre registrar que a AP1 é vinculada ao centro da cidade, a AP2 é vinculada à zona sul, a AP3 é vinculada à zona norte, a AP4 é vinculada a Barra da Tijuca e Jacarepaguá e, a AP5 é vinculada a Zona Oeste.

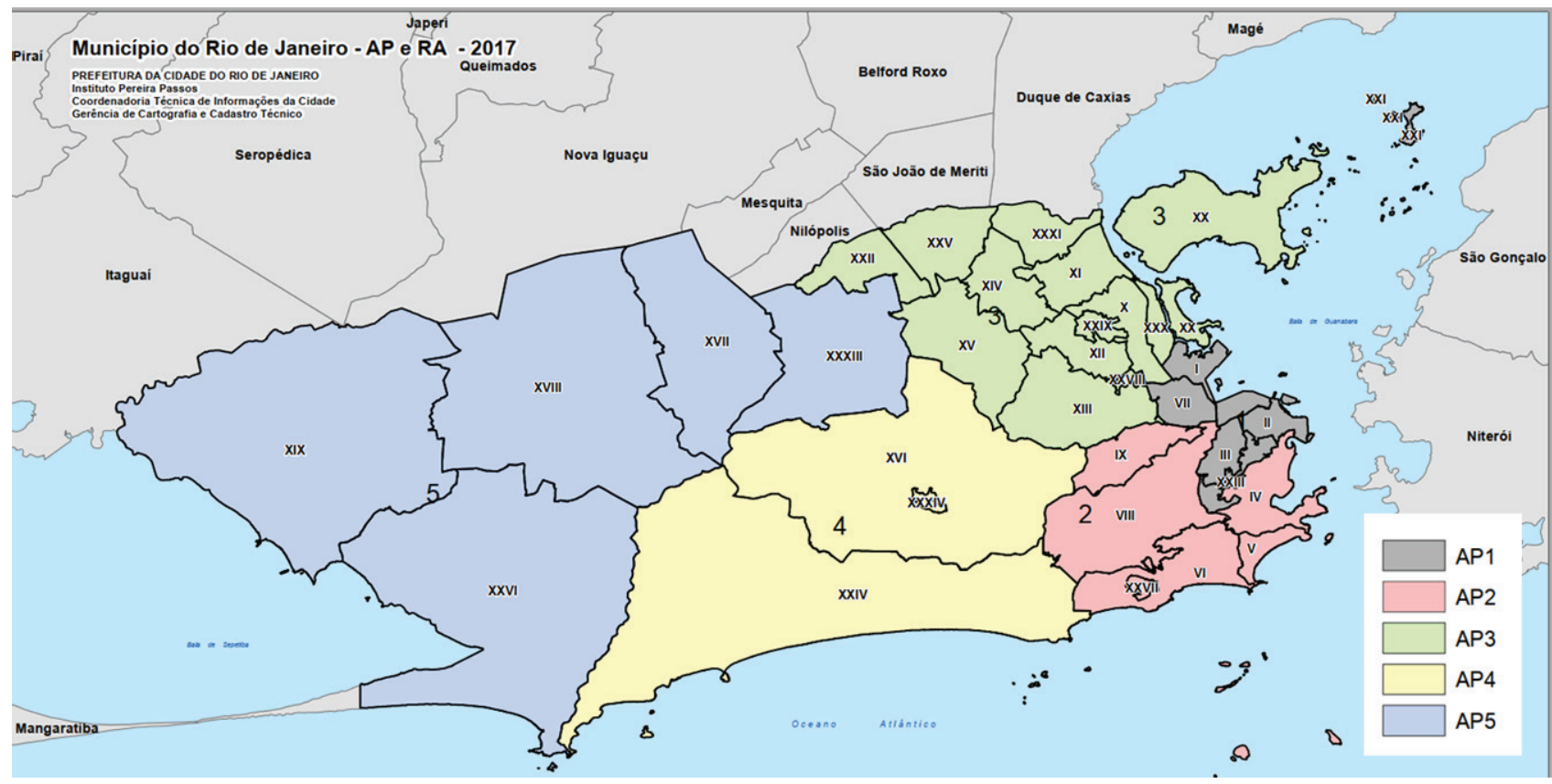

Mapa 1 - Áreas de Planejamento APs da Cidade do Rio de Janeiro

Fonte: Prefeitura da Cidade do Rio de Janeiro (http://www.rio.rj.gov.br/dlstatic/10112/1529762/DLFE-220205.pdf/)

Ainda nas fragilidades apontadas nos encontros, registramos: A14. Ausência de um programa de fomento anual que contemple a manutenção de companhias, como também, o processo de pesquisa e criação artística; A15. Ausência de linhas de financiamento reembolsáveis para o custeio de pequenas produções. Vale ressaltar que a única linha reembolsável encontrada no município é uma linha de distribuição de recursos no setor de Audiovisual para a produção e a comercialização de conteúdo para cinema, TV e novas mídias, sendo no caso, a Linha Rio Global.

Essa Linha tem como objetivo promover a imagem do Rio de Janeiro atra- 
vés do incentivo à produção audiovisual estrangeira na cidade e faz parte do Programa Rio Audiovisual, uma parceria da Secretaria de Estado de Cultura do Rio de Janeiro com a Prefeitura do Rio, através da RioFilme.

No que se refere à circulação na cadeia produtiva da Cultura, a concentração aparece como um dos principais problemas a ser enfrentado: A16. A viabilidade de circulação de ações de Cultura em todas as áreas da cidade se traduz impossível, tendo em vista a insuficiência de equipamentos culturais em todas as regiões. Os editais municipais preveem a circulação de espetáculos e exposições, mas a concentração de equipamentos nos bairros da AP-1, que engloba os bairros do Centro, e da AP-2, que envolve a Zona Sul e Grande Tijuca, e a quantidade de equipamentos culturais nas demais Áreas de Planejamento da cidade impossibilitam que isso ocorra de maneira mais efetiva. Essas concentrações percebidas na circulação apareceram também na distribuição dos recursos voltados para cada segmento artístico-cultural: A17. Na área de Audiovisual, grande parte dos investimentos públicos estão voltados, em sua maioria, para o Cinema, restando ficar prejudicada a parcela de investimento para o desenvolvimento de novos formatos.

Outra fragilidade observada se refere à dificuldade de articulação entre o Poder Público e a iniciativa privada e também entre as secretarias de governo, resultando, inclusive, muitas vezes até mesmo em ações concorrentes: A18. Dificuldade de articulação entre o Poder Público e a iniciativa privada. Diretamente com a iniciativa privada, só identificou-se que havia uma articulação indireta por meio da Companhia Municipal CDURP, responsável pelas obras do Porto MaraviIha que articula com a iniciativa privada. A Secretaria Municipal de Cultura possui equipamentos na região que fazem par- te do projeto Porto Maravilha. E também: A19. Dificuldade de articulação entre a Secretaria Municipal de Cultura e as demais Secretarias da Prefeitura. A articulação se dava principalmente entre a Coordenação de Livro e Leitura e a Secretaria de Educação por meio de um programa desenvolvido no interior das Escolas do Amanhã, o Segundo Turno Cultural, onde as crianças participavam de oficinas culturais. Este projeto começou em 2009, atendendo 152 escolas e 7.600 alunos com 34 oficinas sendo oferecidas.

A partir de 2011, a Coordenação estendeu este programa às Vilas Olímpicas da Secretaria de Esporte e Lazer, onde em 2012, foram realizadas 22 oficinas em 13 Vilas Olímpicas, com um público estimado de 4.412 pessoas. Além disso, surgiram essas questões a serem enfrentadas: A20. As ações de fomento das três esferas de poder não são articuladas e complementares, sendo muitas vezes concorrentes; A21. Os Mecanismos de isenção fiscal - ISS são de difícil aplicação em razão dos mecanismos burocráticos. Para a isenção, são necessárias leis específicas, e quando existe a lei, como é o caso do Circo, a máquina pública tem mecanismos operacionais muito burocratizados que acabam por dificultar a aplicação da lei. Aponta ainda: A22. Dificuldade na aplicação de contratos, convênios e no funcionamento das ações no campo das Artes e da Cultura, implicando fazer uma revisão tributária. De fato, há necessidade de revisão em alguns aspectos e muitos deles escapam da atuação do poder municipal.

Nesse sentido, no campo municipal já havia um pedido formal à Secretaria de Fazenda solicitando a simplificação dos trâmites e a revisão cabível. Dando prosseguimento às fragilidades, registramos: A23. Os dispositivos do capítulo da Cultura estão ultrapassados e precisam ser revistos na Lei Orgânica Municipal. A Lei foi 
criada em 1992 e, desde então, o capítulo referente à Cultura não sofreu qualquer tipo de alteração; A24. Falta intensificar a interlocução com o Poder Legislativo, em especial com a Comissão de Educação e Cultura, de forma a se discutir as questões referentes à Cultura; A25. Ausência de sinalização urbana com simbologia universal em monumentos e locais históricos da cidade; A26. Carência de investimentos para que os bairros atraiam público aos seus equipamentos culturais. A sinalização turística aparecia como uma das metas que o governo do Prefeito Eduardo Paes se comprometia a alcançar até junho de 2013, assumida em seu Plano Estratégico - 2013/2016; A27. A infraestrutura de transporte público não favorece a circulação para tornar-se viável a visitação aos equipamentos culturais, a exemplo de museus localizados em bairros distantes do Centro, como o Museu da Chácara do Céu e o Museu Casa do Pontal, que reclamam que os mesmos não são atendidos por uma infraestrutura de transporte mais eficiente que contribua à visitação em seus museus, o que impede a criação de um circuito cultural que envolva todos os equipamentos culturais da cidade.

No que se refere à acessibilidade, os problemas enfrentados são: A28. Baixo índice de instalações e mecanismos de acesso de pessoas com deficiência aos equipamentos de Cultura da cidade. A média de acessibilidade dos equipamentos culturais fica em $40 \%$, exceto o Cinema, que chega a $90 \%$. No caso da cidade, muitos dos equipamentos culturais não foram pensados para serem equipamentos de Cultura, pois são casas ou sobrados históricos adaptados para receber museus, centros culturais ou bibliotecas. Muitos já criaram formas de atender seus usuários, mas ainda faltam atendimentos adequados, principalmente, às pessoas com deficiência visual e auditiva. A cidade, na maior parte das vezes, ainda não está preparada para receber esse público em seus equipamentos. Ainda com relação ao acesso e uso dos espaços, apontamos essas fragilidades: A27. Valores faciais dos ingressos dispendiosos, mesmo aqueles espetáculos fomentados com verba pública. Esse fator dificulta o acesso de público aos bens e produtos culturais; A29. As manifestações culturais afrodescendentes encontram dificuldade de utilização dos espaços culturais, em especial, os Blocos Afro e as Folias de Reis.

Sobre os acervos, os equipamentos culturais e a regulamentação do artista, registramos: A30. Necessidade de preservação dos acervos, em especial, da produção audiovisual; A31. Concentração de equipamentos culturais, entre públicos e privados em determinadas áreas da cidade, principalmente no Centro e na Zona Sul; A32. Supressão de exibição de filmes de curta-metragem antes dos filmes de longa-metragem; A33. Falta de regulamentação da profissão de artista. Atuação artística de maneira informal no mercado de trabalho.

Após identificarmos essas fragilidades e demandas, foi feito um levantamento, contendo uma síntese de Vocações e Potencialidades(C) identificadas para o Desenvolvimento Cultural, cujo quadro aponta: C1. Presença de Universidades Federais, Estaduais e privadas, que são centros de excelência na formação de alunos e na formulação de pesquisas; C2. Presença de um Instituto Municipal que produz informação e análise para o planejamento e a efetividade das políticas públicas da Cidade do Rio de Janeiro; C3. Presença de escolas municipais e outros equipamentos públicos, em todos os bairros, potencializando o uso de espaços a serem utilizados para as apresentações; C4. Disponibilidade de subvenção às lonas dos circos, de forma que possam abrigar outras atividades artísticas em locais onde não tenham espaços culturais, ou onde os mesmos não possuam pauta; C5. 
Presença de estações de trens, ônibus e metrôs que podem ser espaços de apresentação de diferentes linguagens artísticas; C6. Existência de imóveis municipais desocupados que podem ser utilizados para abrigar condomínios culturais e/ou residências artísticas; C7. Disponibilidade de equipamentos privados, com potencial vocação para a implantação de política pública de Cultura, que podem ser subsidiados pelo Poder Público, em substituição a gastos com a construção de novos espaços; C8. Existência de espaço físico para a implantação de equipamentos culturais, públicos e privados, em áreas distintas dos eixos Centro e Zona Sul.

Nesse quadro, é possível perceber por parte da Prefeitura, um foco no turismo, no desenvolvimento da zona portuária, e na indústria criativa, nas seguintes Metas (D): D1. Implantação do projeto de desenvolvimento da área portuária, o Projeto Porto Maravilha, apresentado pela Prefeitura naquele período, cuja proposta pretendia criar um potencial de construção e de instalação de novos equipamentos culturais, e também, o restauro de equipamentos existentes, em especial, Museus e Centros Culturais; D2. Aproveitamento da divisão geográfica da Cidade, em 5 Áreas de Planejamento, que se subdividem formando um total de $10 \mathrm{e}$, de forma administrativa, dividida em 33 Administrações Regionais; D3. Integração das três esferas de Poder: Municipal, Estadual e Federal; D4. Fixação de percentual mínimo de $1 \%$ da receita do ISS para a aplicação em projetos culturais, incentivados pela Lei Municipal de Incentivo. D5. Valorização do Patrimônio e da Memória Imaterial por meio de tombamentos e preservações.

Essa configuração pretendia potencializar a delimitação de distritos criativos, espaços fundamentais de criação e produção cultural. Identificou-se a existência de escolas técnicas mantidas pela iniciativa privada com potencial para trabalhar em parceria com o setor público. A Cidade do Rio estava se preparando para sediar grandes eventos internacionais - Copa das Confederações e do Mundo, Olimpíadas, Jornada da Juventude, ICOM, dentre outras ações, conforme destacava o Plano Estratégico 2013-2016.

Nesse Plano, a Prefeitura destacou a Indústria Criativa como uma referência, em especial, nos setores de Moda, Design e Audiovisual. E mencionava o grande potencial turístico da Cidade, sendo considerado o principal destino turístico nacional e internacional do país. Os espaços abertos, em geral, espalhados nos diversos bairros com potencial de utilização para a ocupação artística e cultural. A presença de eventos de rua que misturam diversas linguagens artísticas e contribuem para a criação de novas cenas e intervenções e a existência de um Centro Histórico rico em edificações marcantes em constante preservação.

Somado ao quadro apresentado, esse trabalho, - realizado em 2012, da qual fiz parte, juntamente com Bruna Carvalho, na condição de consultoras do MinC/UFBA para a criação do Plano Municipal de Cultura do Rio de Janeiro, - envolveu também, apontarmos as diretrizes que foram retiradas do resultado da $1^{\circ}$ Conferência Municipal de Cultura do Rio de Janeiro, - que englobou as temáticas nacionais e as questões da cidade e desenvolveu-se sob o tema "Integração e Direito à Cidade", com a Plenária Final, realizada nos dias 24 e 25 de outubro de 2009, nas dependências do Palácio Gustavo Capanema, pela Secretária Municipal de Cultura Jandira Feghali, na gestão do Prefeito Eduardo Paes.

Registramos as Diretrizes (E) desta $1^{\text {a }}$ Conferência Municipal de Cultura do Rio de Janeiro, e também do Plano Diretor da Cidade e da Lei Orgânica do Município, conforme a seguir: E1. Garantir a liberda- 
de, a integração e o respeito a todas as manifestações culturais, tendo a diversidade cultural como patrimônio e referência permanente; E2. Estimular a produção, a valorização e a difusão da Cultura em suas múltiplas manifestações; E3. Estimular a ampliação do acesso e a difusão das atividades criativas da cidade, contribuindo com a melhoria da qualidade de vida da população; E4. Ocupar os espaços públicos com atividades culturais integrando as comunidades; E5. Promover o desenvolvimento cultural dentro das comunidades; E6. Incentivar e difundir produções artísticas e pesquisas acadêmicas que destaquem, valorizem e contribuam para a construção da memória e a ampliação do conhecimento sobre a Cidade do Rio.

Essas diretrizes referem-se, ainda, ao acesso, à diversidade, à melhoria de condições dos espaços culturais, dentre outras demandas: E7. Proporcionar o estímulo à participação social, assegurando que os espaços municipais de Cultura sejam abertos para todas as linguagens artísticas e manifestações culturais; E8. Diversificar as atividades culturais da rede de espaços culturais municipais, democratizando o acesso às pautas, através de um sistema público e transparente, priorizando as diversidades culturais locais; E9. Estimular a construção, ou reforma, de novos espaços cênicos distribuídos pela cidade, a fim de atender às diferentes regiões e à diversidade de manifestações artístico-culturais, com especial aplicabilidade à Dança; E10. Promover o desenvolvimento das indústrias e serviços criativos na Cidade do Rio de Janeiro; E11. Assegurar a participação social, institucionalizando e democratizando a gestão dos recursos públicos de Cultura e a formulação das políticas culturais do município.

$\mathrm{Na}$ sequência, observamos que muitas das diretrizes estavam voltadas para a valorização do artista local, o papel da Cultura enquanto potencial de criação e como uma política de Estado, a necessidade de capacitação dos profissionais da área e a elaboração de uma cartografia local: E12. Assegurar que a Cultura seja uma política de Estado, garantindo uma estrutura organizacional e orçamentária adequada á política cultural; E13. Valorizar o artista local através do estímulo à capacidade criativa do cidadão, à manutenção de grupos culturais tradicionais e ao apoio à produção artística e às manifestações culturais das diversas áreas; E14. Fortalecer o papel da Cultura e o potencial criativo da cidade como vetores importantes da economia do Rio de Janeiro; E15. Promover a capacitação de gestores culturais garantindo o aperfeiçoamento dos serviços culturais a serem realizados nos equipamentos municipais; E16. Garantir a criação de um escritório de apoio à elaboração de projetos culturais; E17. Promover a identificação das diversas manifestações culturais para a criação de uma cartografia cultural local.

Nessas diretrizes, dentre outros aspectos mencionados, é possível perceber a necessidade de atentar-se para as legislações específicas do setor, o intercâmbio cultural, a integração transversal entre instituições e secretarias, a preservação do patrimônio e a inclusão social: E18. Assegurar mecanismos de fomento para a gestão da Cultura e da política cultural; E19. Promover a revisão e o aprimoramento das leis tributárias no campo das artes; E20. Assegurar o cumprimento das legislações específicas para os setores artísticos e culturais da Cidade do Rio de Janeiro; E21. Incentivar a integração transversal das instituições públicas com as instituições privadas na consolidação das políticas públicas; E22. Assegurar a integração entre as Secretarias Municipais na promoção de projetos de cunho cultural, na simplificação dos entraves burocráticos; E23. Estimular o aperfeiçoamento dos diversos profissionais da Cultura, por meio de apoio e incentivo ao 
intercâmbio cultural com outros países, com outros estados e municípios; E24. Fortalecer os Poderes Municipais, com a colaboração da comunidade, na proteção do Patrimônio Cultural por meio de inventários, tombamentos, desapropriações e outras formas de acautelamento e preservação; E25. Valorizar e promover o cadastro atualizado, organizado sob a orientação técnica, do Patrimônio Histórico e do Acervo Cultural Público e privado; E26. Promover a preservação documental, modernizando a rede de Arquivos de forma a torná-los adequados a receber todo tipo de acervo e E27. Reconhecer a Cultura como indutora da inclusão social. A partir desses diagnósticos existentes, de um olhar, escuta e observação com os diversos agentes da cidade, apresentamos alguns tópicos levantados, naquele momento, como prioridades.

No tocante à gestão, a prioridade é estabelecer e implementar uma Política de Estado $(F)$, conforme a seguir: F1. Adesão do Rio ao Sistema Nacional de Cultura, com a aproximação, pactuação e parcerias em programas e ações com os governos estadual e federal em conjunto com a sociedade civil, dentro de uma visão sistêmica; F2. Criação de um canal de diálogo com a população através da continuidade de realização da Conferência Municipal de Cultura, para discutir as diretrizes e metas de curto, médio e longo prazos, a fim de traçar um planejamento de ações de acordo com as urgências levantadas por aqueles que vivem diariamente a cidade.

As diretrizes também se referiam ao órgão gestor, ao orçamento da pasta de Cultura, editais, criação de fundo, conselho, câmaras setoriais e a formação de um fórum permanente: F3. Fortalecimento da Secretaria Municipal das Culturas, com a elaboração de um Plano de Cargos e Salários e concursos públicos para a composição, valorização e qualificação do quadro de funcionários com cursos de formação e capacitação na área de gestão cultural; F4. Criação e instalação de Câmaras Setoriais dos segmentos artísticos - Teatro, Dança, Circo, Música, Artes Visuais. Cultura Digital, a fim de se levantar as diretrizes específicas de cada área, para constar de um Plano Municipal de Cultura e planejar ações e programas culturais; F5. Instalação do Conselho Municipal de Cultura, como importante instrumento de controle social, acompanhamento e fiscalização da gestão municipal; F6. Criação de um Fundo de Cultura, cuja verba, não contingenciável, será executada através de um edital de fomento e apoio, principalmente às ações que não são apoiadas pelo mercado; F7. Criação de um Sistema de Informações Culturais - com levantamento dos grupos, equipamentos, entidades e agentes que atuam na área cultural; F8. Criação de um Fórum Permanente de Cultura como mais um canal de diálogo e construção de políticas públicas de Cultura e F9. Orçamento de no mínimo $2 \%$ para a Cultura para além do que estabelece a PEC 150 de $2 \%$ para União, $1,5 \%$ para os Estados e 1\% para os Municípios.

No que se refere à Economia da Cultura $(G)$, que implica fomentar a geração de emprego e renda e o mercado de trabalho, algumas das principais necessidades apontadas, durante os encontros presenciais, foram: G1. Lançamento de editais, prêmios e outras formas de seleção públicas de fomento e apoio às ações culturais; G2. Desenvolver uma política para a administração da Rede de Teatros, como também, dotar as casas de espetáculo de equipamentos de som, luz e demais condições de funcionamento, com a melhoria, a conservação e a manutenção desses espaços; G3. Redefinição da Lei de Incentivo Municipal à Cultura, através de audiências públicas para discutir possíveis mudanças e adequações aos mecanismos de patrocínio, a partir de definições com a população sobre as áreas de prioridade a serem contempladas; G4. De- 
finição de uma política para a RioFilmes, com o lançamento de editais de estímulo e apoio à criação de roteiro, produção e distribuição de filmes, de forma a potencializar a vocação do Rio de Janeiro como importante polo de audiovisual e G5. Implementação de uma política de distribuição e circulação dos bens culturais através de seleções públicas, como editais de fomento às artes e/ou prêmios para as culturas populares, culturas ciganas, culturas indígenas, etc.

Já na área de Patrimônio Cultural, foi sugerida a implementação de uma política de patrimônio cultural material e imaterial para apoiar a preservação, o registro e a valorização da memória e identidades locais. Com relação à Participação e Direito à Cidadania, ressaltou-se a importância do acesso e da fruição, através de Programas de popularização e/ou distribuição de ingressos, vale-cultura, loterias e campanhas para ampliar o acesso e a fruição à Cultura.

No que tange à Formação e Capacitação $(H)$, foram levantadas as seguintes proposições: H1. Programas de formação e capacitação, em convênio com universidades, fundações, centros de pesquisa, Sebrae, Sesc, Senac, Sesi, voltados para a gestão cultural, a formulação de projetos e a prestação de contas; H2. Investimento em pesquisas, mapeamentos, censos culturais, a fim de se fazer um levantamento e estudo das cadeias produtivas e do movimento do setor, assim como, um diagnóstico da gestão, da política implementada e uma avaliação de seus resultados junto à população no que se refere à geração de emprego e renda, à manutenção de serviços e ao PIB da Cultura como importante fator de desenvolvimento da economia; H3. Definição de uma política para a RioArtes, com a retomada do Programa de Bolsas de Apoio às Pesquisas voltadas para as Artes; H4. Desenvolvimento de uma política de investimento nas bibliotecas públicas, com parcerias público-priva- das para a aquisição de novos títulos, a formação/capacitação de seus profissionais e a criação de novas bibliotecas e H5. Criação de redes de pensamento cultural, ciência e tecnologia.

Com relação às Políticas Transversais (I), para implementar ações da Cultura com outras áreas, sugeriu-se: I1. Criação de uma política da Cultura com a Educação de maneira a pensar a escola como espaço de cidadania, de conhecimento da história e memória da cultura brasileira, com o ensino das Artes e a transmissão oral de mestres da sabedoria popular, e, assim, diminuir ou eliminar a repetência e a evasão de alunos, adquirindo o pertencimento, o interesse e o envolvimento com as manifestações, fazeres e saberes locais e a possibilidade de exercer as suas potencialidades de criação e imaginação; 12. Criação de uma política de Cultura pactuada com a Comunicação de forma a democratizar os espaços às produções locais, à diversidade cultural, às diferentes linguagens, a fim de espelhar as realidades sem padronizá-las numa única imagem.

E foram apontadas também diretrizes de Políticas Transversais da Cultura com as áreas do Turismo e do Meio Ambiente: I3. Criação de uma política combinada entre a Cultura e o Turismo, com o objetivo de valorizar as potencialidades artísticas e o intercâmbio cultural ao estimular os visitantes da cidade a conhecer e prestigiar as Artes e a Cultura brasileira; 14. Criação de políticas públicas transversais da Cultura com o Meio Ambiente para uma visão sistêmica e integrada que valorize a vida, o coletivo, a cidade, o meio, o entorno, o viver junto, a cultura da paz, que se reflete nas ações de: Tratamento do lixo evitando ou combatendo o desperdício e o abandono da cidade; Valorização do patrimônio público; Segurança nas ruas; Melhoria no sistema de iluminação; Conservação e preservação do meio ambiente; Preven- 
ção de doenças; Cuidado com o espaço público e Políticas de cidadania.

Passada toda essa longa etapa, diante da amplitude de algumas áreas, de imensos territórios com inúmeros bairros e regiões administrativas, ressaltou-se a necessidade de se desdobrar os 12 encontros presenciais, realizados com os agentes culturais, para captar e incluir suas carências e potências locais e regionais, de uma rica diversidade cultural. Porém, o segundo momento de elaboração do Plano Municipal de Cultura, - que previa o trabalho de campo, através da realização de 10 encontros territoriais, divididos de acordo com as cinco Áreas de Planejamento, que compõem o Município e suas subdivisões, - foi interrompido em função de ter encerrado a parceria da Secretaria Municipal de Cultura com o Ministério da Cultura e a Universidade Federal da Bahia. Soma-se o fato de ter ocorrido nesse período uma mudança na gestão da SMC RJ, com a saída de Emílio Kalil, que permaneceu de 2010 a 2012, sendo substituído por Sérgio Sá Leitão, que ficou de 2012 a 2015, seguido de Marcelo Calero, que assumiu a SMC RJ, no período de 2015 a maio de 2016, e Júnior Perim, em 2016. Todos esses secretários Kalil, Sá Leitão, Calero e Perim, assumiram a pasta da Cultura na gestão do Prefeito Eduardo Paes, que permaneceu de 2009 a 2017.

Na gestão do Secretário Sérgio Sá Leitão foi realizada a $2^{\text {a }}$ Conferência Municipal de Cultura do Rio, nos dias 5 e 6 de agosto de 2013, no Centro Cultural João Nogueira - Imperator, no Méier, - que contou com a presença de 524 participantes de diversas regiões da cidade e 25 delegados, que foram eleitos pelos participantes para representarem a capital na Conferência Estadual de Cultura, uma vez que considerou-se que o Conselho Municipal de Cultura do Rio de Janeiro precisava de uma reestruturação. Para Sá Leitão, o que a conferência aprovou foram propos- tas, pois, segundo ele, para reformular o Conselho Municipal de Cultura, é preciso mudar a lei.

No primeiro dia de conferência, a representatividade do atual Conselho Municipal de Cultura foi posta em xeque. $\mathrm{O}$ ator Patrick Sampaio, que ocupava a cadeira do teatro, renunciou ao posto dizendo que o processo de eleição para o CMC, que o levou à cadeira como Conselheiro foi algo de que a grande maioria dos agentes da Cultura na cidade não chegou a tomar conhecimento. "Não me sinto representativo. A Prefeitura do Rio de Janeiro tem acumulados nos últimos 3 anos mais de $R \$ 100$ milhões gastos em publicidade e elogio de si, enquanto processos de importância inestimável, como a composição de um Conselho Municipal de Cultura e esta própria Conferência, são negligenciados nesse sentido". Em resposta, Sá Leitão disse: "Eu lamento que ele tenha renunciado - disse Sérgio Sá Leitão, secretário municipal de Cultura. - Acho que o conselho perde porque ele poderia dar boas contribuições e perde também porque é a partir de espaços como o conseIho que podemos debater as mudanças"3. Vale ressaltar que nenhuma dessas gestões, desde 2012, deu continuidade para viabilizar o Plano de Cultura, processo esse que só foi, enfim, retomado seis anos depois, em 2018, quase no final da gestão de Nilcemar Nogueira, que assumiu o cargo de Secretária, no período de 2017 a 2019. Consta na página da Secretaria Municipal de Cultura do Rio de Janeiro, que o Conselho Municipal de Cultura havia feito uma reunião aberta no dia 28 de fevereiro de 2018, para apresentar a minuta de revisão do Decreto e, também, anunciar o

3 Matéria veiculada no jornal O Globo, por Cristina Tardáguila, 08/08/2013, no site: https://oglobo.globo. com/cultura/cariocas-pedem-reestruturacao-do-conseIho-municipal-de-cultura-9434532). 
funcionamento das pré-conferências e da Conferência Municipal de Cultura. De fato, durante a gestão da secretária Nilcemar Nogueira, o CMC realizou reuniões semanais, além de alguns encontros temáticos com especialistas de diversas áreas e representantes de órgãos públicos como a Secretaria Municipal de Educação, a Riotur, o IRPH (Instituto Rio Patrimônio da Humanidade) e a subsecretaria da Pessoa com Deficiência. O Conselho é formado por 24 membros, sendo 12 oriundos do poder público e 12 da sociedade civil.

No dia 28 de abril, seria a Conferência Municipal de Cultura e se definiria o conselho. ${ }^{4}$ Mas, na verdade, a $3^{a}$ Conferência Municipal de Cultura, ocorreu nos dias 28 e 29 de maio. E foram realizadas cinco pré-conferências, uma por Área de Planejamento (AP), abrangendo todos os bairros e regiões da cidade. A primeira pré-conferência, realizada no dia 9 de maio, no Centro de Artes Calouste Gulbenkian, reuniu produtores culturais dos bairros da região Central que integram a AP 1, composta por Zona Portuária, Centro, São Cristóvão, Rio Comprido e Santa Teresa. $E$ as pré-conferências seguinte aconteceram na Zona Oeste (AP 5), em 12 de maio, no Teatro Estadual Arthur Azevedo; Zona Sul e Tijuca (AP 2), em 15 de maio, na Sala Municipal Baden Powell; e na Zona Norte (AP 3), dia 19 de maio, na Arena Carioca Fernando Torres. A pré-conferência da AP 4 (que engloba Cidade de Deus, Jacarepaguá, Barra e Recreio), que seria realizada em 5 de maio, foi adiada devido aos violentos confrontos ocorridos na Cidade de Deus naquele último dia 3 , o que gerou instabilidade e dificuldade de acesso à região de Jacarepaguá ${ }^{5}$.

4 Cf. 05/02/2018, site da SMC RJ: http://www. pcrj.rj.gov.br/web/smc/exibeconteudo?id=7669185).

5 Cf. 08/05/2018, site da SMC-RJ: http://www.rio. rj.gov.br/web/smc/exibeconteudo?id=7943666).
Essa $3^{a}$ Conferência Municipal de Cultura pretendia resultar em três grandes legados: a criação do Sistema Municipal de Cultura, a proposta de reformulação da Lei Municipal de Incentivo à Cultura (Lei do ISS) e a criação do Fundo Municipal de Cultura, o que impactará nas políticas culturais e no financiamento à cultura em nossa cidade", defendeu a secretária Nilcemar. "Estamos abrindo a possibilidade de construção de uma política pública com participação efetiva da população". Segundo ela, a aprovação do Projeto de Lei é de extrema importância para a cultura carioca. "Permitirá que o investimento na cultura seja maior e realizado a partir de uma política de estado, não de governo", afirmando que o PL seria votado em primeira discussão na sexta-feira, dia 15 de agosto, às $14 \mathrm{~h}$, no Plenário da Câmara Municipal ${ }^{6}$.

Conforme consta na página da Prefeitura da Cidade, a Câmara dos Vereadores do Rio pretendia colocar em votação, no dia 15 de fevereiro, o Projeto de Lei $1.029 / 2018$, que cria o Sistema Municipal de Cultura do Rio de Janeiro (SIMC). O SIMC integra o Sistema Nacional de Cultura e o Sistema Estadual de Cultura, constituindo-se no principal articulador das políticas públicas de cultura da cidade. Se aprovado, o PL faria com que a cidade tenha, pela primeira vez, um Plano e um Fundo Municipal de Cultura para financiar projetos de arte, para auxiliar no desenvolvimento humano, social e econômico, com pleno exercício dos direitos culturais $^{7}$. Mas, embora Nilcemar tenha realizado as pré-conferências preparatórias, que resultaram na $3^{a}$ Conferência Municipal de Cultura, e se pretendesse

\footnotetext{
6 Cf. 07/05/2018, site da SMC-RJ: http://www.rio. rj.gov.br/web/smc/exibeconteudo?id=7939427).

7 Cf. 14/02/2019, sitedaPrefeituradoRiode Janeiro: http://prefeitura.rio/web/smc/exibeconteudo?id=9179687)
} 
colocar em votação esse Projeto de Lei da Cultura, vimos que esse processo foi novamente interrompido com a sua saída da Secretaria, sendo substituída por Mariana Ribas, que permaneceu somente por cerca de seis meses no cargo, atualmente ocupado pelo advogado Adolpho Konder, que tomou posse no dia 2 de setembro de 2019 e ainda permanece na função.

Durante a transição, devido à saída de Nilcemar Nogueira, a Comissão Permanente de Cultura e os integrantes do Conselho Municipal de Cultura do Rio - CMRJ, agendaram uma Reunião Extraordinária com a nova Secretária empossada, Mariana Ribas, na tentativa de dar continuidade ao Plano de Cultura e aprovar o Projeto de Lei 1029 do Sistema Municipal de Cultura. Na pauta, também havia a necessidade de retornar com a Lei de Diretrizes Orçamentárias - LDO 2020 , a fim de tratar de recursos no orçamento para os territórios das AP5, AP4, AP3, AP2, AP1. Naquele momento, também conseguiram agendar uma reunião do Conselho de Cultura com a Comissão Técnica de Estudos Orçamentários e Recursos e a retomada da Política e o eixo de acessibilidade com articulação federal e um encontro da Comissão da SMC RJ e o Conselho Municipal de Cultura - CMC na gestão da Secretaria Municipal de Desenvolvimento Social.

Os integrantes do Conselho Municipal e da Comissão Permanente de Cultura compareceram também na Audiência Pública do Orçamento da Cultura, realizada no dia 22 de maio de 2019, no Plenário da Câmara Municipal do Rio, na Cinelândia, que tratou da Lei que estima a Receita e fixa a Despesa do Município do Rio de Janeiro para o exercício financeiro de 2020 , para as áreas de Assistência Social, Direitos Humanos e Cultura.

Porém, a Secretária de Cultura Mariana Ribas não esteve presente nessa au- diência e a conselheira Andrea Chisorin, uma das integrantes que estava representando o CMC-RJ, considerou muito "triste não ter orçamento da Cidade para a Cultura. Não há lugar para a Cultura na gestão de Marcelo Crivella, estamos como paisagem no cenário", disse ela. Na avaliação de Chisorin, "vê-se com isso desmontar a política cultural, de uma Secretaria de Cultura que só aposta no privado, ou seja, via ISS, que significa a privatização dos espaços públicos e na precariedade" (Depoimento colhido na Câmara Municipal no dia 22 de maio de 2019). Segundo Suelyemma Franco, assessora do mandato de Reimont Otoni (PT-RJ), - vereador que preside a Comissão de Cultura da Câmara Municipal do Rio, - nessa Audiência Pública, o que chamou a atenção foi a previsão de editais condicionados à execução de emendas federais, tendo sido mencionada a Emenda Federal da Deputada Federal Benedita da Silva. Para os editais mencionados: Edital dos Pontos de Cultura; Edital de Música; Reformas e Manutenção de Arenas, não foram apresentadas as correspondentes rubricas orçamentárias.

Sobre todo esse processo, é importante observar que, nos 12 encontros que realizamos na primeira etapa, as discussões internas entre a equipe de consultoria e a Secretaria Municipal de Cultura, inicialmente foram pensadas a partir do recorte de cinco eixos temáticos para orientar a subdivisão dos seguintes grupos de trabalho: Identidade, Diversidade e Patrimônio Cultural; Cidade, Cidadania e Direitos Culturais; Economia da Cultura; Gestão da Cultura e Políticas Transversais de Cultura. Os resultados foram anexados às propostas da I Conferência Municipal de Cultura, realizada em 2009, incluindo as metas definidas para a área da cultura no Plano Estratégico da Prefeitura do Rio até 2016, com o alinhamento às Metas do Plano Nacional de Cultura e demais documentos, pesquisas e diagnósticos atualizados. 
Pretendia-se, assim, definir posteriormente as diretrizes e metas que deveriam constar do documento final, com o objetivo previsto de resultar no Plano Municipal de Cultura do Rio de Janeiro. A meta principal que buscou-se atingir nesta etapa foi envolver a efetiva participação dos diferentes atores do Estado e da Sociedade, de modo a fornecer subsídios e formular recomendações para a definição de diretrizes, estratégias e políticas públicas direcionadas aos diversos setores culturais, em sintonia com os eixos definidos pela Secretaria de Cultura e demais entes federados, apontando para: o incentivo à produção e amplo acesso à fruição simbólica; o fortalecimento da produção artístico-cultural na economia como setor capaz de gerar trabalho e renda; a promoção da cidadania mediada pela cultura e pela arte, com a elaboração de planos setoriais, definindo uma política específica para cada área.

Afirmou-se, assim, o propósito de se implantar políticas públicas democráticas e permanentes de cultura, como instrumento para atingir as metas e desafios que se apresentam, através de uma gestão compartilhada entre Estado e Sociedade e a integração dos três níveis de governo, de forma pactuada, planejada e complementar. Cumpre observar que a definição de uma política de Estado poderá auxiliar na correção das desigualdades socioeconômicas locais e regionais, de forma a garantir a participação da sociedade nos processos decisórios e o acesso aos bens e serviços culturais, promovendo o desenvolvimento das dimensões: humana, social e econômica.

A formulação e implantação de políticas públicas de Cultura resultam de uma complexa interação entre agências estatais e não estatais. O Estado tem importante papel nesse sistema de múltiplos atores, mas não é o único. Há que se considerar a presença de atores não estatais, como: a sociedade civil através de entidades associativas, as organizações não-governamentais, as redes culturais, o poder legislativo e a iniciativa privada.

$\mathrm{Na}$ perspectiva das políticas públicas, a governança da sociedade atual transcende, portanto, o estatal, impondo a negociação como procedimento usual entre os diferentes atores sociais. Políticas públicas de Cultura podem ser desenvolvidas por uma pluralidade de atores políticos, sociais e não somente pelo Estado, desde que sejam submetidas ao debate e ao crivo públicos como formas de controle social. A democratização do acesso e a participação são essenciais para a completude deste circuito. Indica a amplitude, a universalidade do ato de recepção da cultura, a importância central das políticas culturais, a descentralização e o pleno exercício dos direitos. Neste sentido, a Cultura se converte em elemento substantivo no estabelecimento dos acordos coletivos necessários para poder viver juntos na sociedade, a partir do reconhecimento e da inclusão de todos e todas. A Cultura é interpretação, produto de acordos humanos que possibilitam a concretude da interação social.

O conceito de Cultura cidadã, mais que ser uma ferramenta para reconhecer a existência de algumas práticas sociais, é uma ação social e cultural que orienta a construção de uma ordem social de convivência, através do acompanhamento oportuno de uma política de Estado. Nesse sentido, combina desde a visão política às diversas tramas sociais existentes no cotidiano, para criar condições de acesso à participação do público, numa sociedade cujo marco de ação é a cidade, estimulando a prática da solidariedade e de uma ética cidadã, para que estes sejam os conteúdos fundantes de um pertencimento e identidade coletivos, finalmente, de uma nova cidadania.

A prática de uma Cultura cidadã adquire importância no político, porque rede- 
fine o âmbito do público, quer dizer, aspira a novos pactos sobre a base de novos acordos de conteúdos e também no social, porque aspira a estabelecer uma ordem de interação para a convivência social da cidade. No âmbito cultural porque expressa, na multiculturalidade ou pluralismo cultural, a Cultura da vida cotidiana é reconhecida como assunto de interesse público.

Por tudo que significa e representa a Cultura na vida da cidade, do município, do país e do mundo, toda e qualquer política pública de Cultura implica ouvir muitas vozes e realidades dentro do processo coletivo de construção de caminhos para a cidade - no caso, a do Rio de Janeiro. Embora os gestores da Secretaria de Cultura tenham decidido desfazer-se dos 5 eixos temáticos norteadores do plano, que são inspirados nas questões trazidas pelo Documento-base da Conferência Nacional de Cultura, optei por mantê-los neste artigo para efeito de análise e reflexão, de acordo com a seguinte divisão:

\section{Eixo 1: Identidade, Diversidade, Patrimônio Cultural}

Este primeiro eixo do plano trata da dimensão simbólica da Cultura, que fundamenta-se na ideia de que é inerente aos seres humanos a capacidade de simbolizar, que se expressa por meio de línguas,valores, crenças e práticas. Nesse conjunto de diferentes significados no campo social, cultural, na política, na economia, são articuladas e inauguradas instituições, profissões, atores, práticas, teorias, linguagens, símbolos, ideários, valores, interesses, tensões e conflitos que acontecem e se movimentam na cidade.

O texto-base da Conferência Nacional de Cultura orienta que é preciso considerar que a diversidade cultural tornou-se tão essencial quanto à biodiversidade para o futuro do planeta e da humanidade. Tor- nou-se tão vital hoje, demandando, inclusive, uma Conferência da UNESCO, realizada em outubro de 2005, a qual discutiu e aprovou uma Convenção Internacional Sobre Diversidade Cultural. Há uma relação dialética entre identidade e criatividade. Se a identidade é um sistema de significados que se fundamenta na memória, a criatividade é o processo de produção de novos significados, que simbolizam para o futuro. Os espaços de memória, como os museus, arquivos e bibliotecas, têm, portanto, uma grande importância social e política. A memória coletiva necessita de suportes para manter-se disponível e em permanente ressignificação, cumprindo a função de guardar, conservar e disponibilizar acervos, uma vez que essas instituições contribuem para a extensão dos direitos culturais.

Para se definir uma política pública de Cultura, deverão ser observados todos os elos que compõe este amplo Sistema Cultural: criação, invenção e inovação; difusão, divulgação e transmissão; circulação, intercâmbio, trocas, cooperação; análise crítica, estudo, investigação, pesquisa e reflexão; fruição, consumo e públicos; conservação e preservação; organização, legislação, gestão e produção de Cultura. Uma política que enfatize, além dos segmentos artísticos, toda a gama de expressões que caracterizam a diversidade cultural brasileira. Artes populares, eruditas, de massas, embora mereçam a mesma atenção por parte do Estado e se misturem no mundo contemporâneo, as culturas indígenas, afro-brasileiras, ciganas e populares exigem ações, programas e projetos específicos de proteção garantida na Constituição.

Assim como as fronteiras e os territórios estão mais flexíveis nas Artes, mas ainda assim, cabe às instituições culturais compreender as especificidades de cada uma e, ao mesmo tempo, estarem atentas às novas linguagens, manifestações e expressões e suas convergências, inclusive, digitais. 


\section{Eixo 2: Cidade, Cidadania e Direitos Culturais}

A cidade é vivida e descrita física e simbolicamente por cada um de forma diferente, uma cidade preenchida pelas cidades particulares (CALVINO, 2006). É, antes de tudo, uma realidade múltipla, percebida, entendida e interpretada por olhares distintos como um fenômeno mental, físico, social, econômico e cultural. É, ao mesmo tempo, personagem e objeto de investigação. Um potencial espaço de produção, intervenção e trocas culturais, garantia e partilha de direitos e deveres e acesso a bens culturais.

A Cultura da cidade precisa ser pensada a partir dos seus múltiplos atores e com todos os segmentos da sociedade, seus agentes individuais e coletivos, com suas potencialidades criativas, suas diferentes formas de expressão e manifestação cultural, de seus territórios de identidade, do seu patrimônio natural, ambiental, material e imaterial, inventado e recriado. É com e para esses sujeitos, que se justifica pensar nas prioridades que deverão estar contidas em um Plano Municipal de Cultura do Rio de Janeiro. A cidade revela também a divisão de mundos. Um abismo separa esses mundos de bairros nobres das favelas e subúrbios, ao mesmo tempo geograficamente tão próximos numa disputa do controle e da disciplina da territorialidade comum, pública e coletiva. Na contramão, o carnaval, a procissão, a folia de reis, o circo, o teatro de rua, a arte urbana e outras expressões do humano escapam do conflito e pedem passagem. De alguma forma se dissipa por instantes a linha divisória, a separação, a tensão, o abismo que os separa para dar lugar ao campo simbólico, religioso, do imaginário se expressar.

As cidades passam por constante construção e desconstrução ocasionadas por vários fatores, crescimento da população, especulação imobiliária, alterações do cenário urbano, impulsionados pelo poder econômico, a construção de novos bairros e a necessidade de uma política pública que estabeleça o ordenamento das cidades visando integrar a sua população. Uma política que aponte caminhos para resolver a deterioração dos centros históricos, a degradação e a violência ocasionadas pelo abandono de antigos bairros, a falta de moradia, a falta de uma dinâmica visando à sustentabilidade do patrimônio cultural. Pensar ações que aliem o desenvolvimento econômico e social das cidades e a valorização do patrimônio, visando preservar a sua memória e o bem-estar dos seus habitantes. A cidade não pode ser encarada como mercadoria, precisa ser vista como lugar que congregue e agregue valor simbólico para seus habitantes respeitando suas delimitações e espaços.

É no espaço público da cidade que ocorrem ou se encolhem históricas manifestações populares e onde se revela a transformação desses cenários e os novos contornos da cidade contemporânea. Como pensar nas condições e na distribuição mais igualitária desses espaços da cidade na atualidade? Como os agentes de cultura se apropriam do uso do espaço público? Como dialogam e são acessadas pelos habitantes da cidade?

Os criadores, inventores e inovadores, representados por artistas, cientistas e intelectuais, vinculados aos universos culturais, acadêmicos ou populares, têm certamente grande relevância no sistema cultural, pela inauguração de ideários, práticas e produtos culturais. Porém, o cidadão comum não deseja mais ser apenas o público receptor dessas manifestações, cada vez mais revela o interesse em também ocupar os espaços das ruas e das redes sociais para se manifestar e se fazer representar, mostrar sua identidade, e participar do processo criativo extrapolando os limites e as fronteiras existentes entre palco/plateia e artista/público. 
Nesse aspecto, a Constituição de 88 é explícita: "O Estado garantirá a todos o pleno exercício dos direitos culturais." Trata-se da dimensão cidadã deste segundo eixo do Plano de Cultura, que afirma que os direitos culturais são parte dos direitos humanos. De acordo com os documentos internacionais, da ONU e da UNESCO, já reconhecidos pelo Brasil e a Constituição Federal de 1988, pode-se concluir que os direitos culturais são os seguintes: direito à identidade e à diversidade cultural; direito à participação na vida cultural, que inclui os direitos à livre criação, livre acesso e livre participação nas decisões de política cultural; direito autoral e direito/dever de cooperação internacional. Nas leis, convenções e declarações universais criadas, que se referem à proteção dos bens culturais, do patrimônio mundial cultural e natural; da proteção e promoção da diversidade das expressões culturais, dos direitos das pessoas pertencentes às minorias nacionais, étnicas, religiosas e linguísticas, cabe ressaltar ainda a Recomendação sobre a Salvaguarda da Cultura Tradicional e Popular, uma recomendação para os Estados apoiarem a investigação e o registro dessas manifestações, sobretudo pelo risco da Cultura popular perder seu vigor diante da indústria cultural.

As cidades e os governos locais de todo o mundo aprovaram, em 2004, a Agenda 21 da Cultura, como documento orientador das políticas culturais locais, onde assumiram como base de compromisso os direitos humanos, a diversidade cultural, a democracia participativa e a criação de condições para a paz. Nessas cidades, as populações pobres permaneceram por muito tempo excluídas das oportunidades de trabalho, cultura e lazer e os equipamentos culturais estavam situados no centro urbano ou em regiões mais ricas da cidade. A instalação de espaços culturais, nessas regiões marcadas pela exclusão, é um dos pontos cruciais para uma política de descentralização que têm um caráter geopolítico e socioeconômico.

Reverter essa divisão, entre centro/ periferia/subúrbio, deverá ser substituída por uma nova visão das cidades, que identifica no território urbano uma variedade de regiões, com seus próprios centros e periferias. Outro fator a considerar, é que as políticas públicas de Cultura podem ser desenvolvidas por uma pluralidade de atores políticos, sociais, não somente o Estado, desde que tais políticas sejam submetidas obrigatoriamente a algum controle social, através da instalação de conselhos, no mínimo paritários, debates, fóruns e crivos políticos. Apesar do importante papel dos trabalhadores da Cultura, não existe sistema sem que outros momentos, instituições e atores estejam contemplados e acionados. Tais processos são vitais para a democratização da Cultura. A questão da transmissão e da difusão da Cultura aparecem, desta maneira, como tema essencial a ser enfrentado em políticas culturais, e as esferas da fruição, acesso e participação também são essenciais para a completude deste circuito.

Indica a amplitude e a universalidade do ato da recepção da Cultura, a importância central das políticas culturais. Neste sentido, a Cultura se converte em elemento substantivo para estabelecer os acordos coletivos necessários para poder viver juntos na sociedade, a partir do reconhecimento e da inclusão de todas e todos.

\section{Eixo 5: Políticas transversais da Cultura}

A Cultura adquiriu um lugar singular e relevante na atualidade. Cabe propor, portanto, uma centralidade para a Cultura. Tal centralidade nos obriga a pensá-la como dimensão transversal, porque perpassa toda a complexa rede que compõe a sociedade atual. Como a cultura perpassa diferentes esferas sociais, torna-se 
substantivo analisar suas interfaces, em especial com áreas afins, como Educação e Comunicação. Para isso, a definição de uma política transversal da Cultura com essas áreas, tem como desafio ultrapassar as ações e parcerias pontuais e apontar ações e programas continuados, com base no cruzamento de diagnósticos, diretrizes e metas a serem alcançadas por esses setores, dentro de uma visão sistêmica, de forma a impactar nas realidades locais e na sociedade como um todo. Nos tempos contemporâneos, há uma proliferação de estudos, políticas e práticas culturais que articulam Cultura e Identidade, Cultura e Desenvolvimento, Cultura da Paz, Cultura e Diversidade, que confirmam o valor da Cultura. Ao mesmo tempo, que comparece como um campo social e singular, simultaneamente transversa com todas as outras esferas sociais, como figura quase onipresente (RUBIN, 2007).

A natureza é indissociável da Cultura, desde o seu conceito, integrando uma série de formas de vida, identidades, cosmovisões, imaginários e manifestações simbólicas de todas as matrizes formadoras da Cultura brasileira. Essas são premissas do texto-base da segunda conferência do Ministério da Cultura, que tomou o ensinamento dos povos indígenas como um princípio organizador das políticas públicas de Cultura no Brasil.

O Plano Municipal de Cultura do Rio deverá seguir na linha do Plano Nacional de Cultura, que projetou suas diretrizes tendo como referência a biodiversidade e sua relação com os modelos de manejo assentados em culturas ancestrais dos povos ameríndios. A valorização das formas culturais e tecnológicas, que preservam a natureza, deve integrar-se a formas de uso sustentável das florestas e dos conhecimentos associados à experiência dos povos que nela habitam. A política cultural não pode estar alheia, portanto, à crise ambiental, que se torna mais grave a cada dia, até mesmo porque decorre de um componente cultural: o modo de vida consumista que explora exaustivamente os recursos naturais.

A capacidade de criar é inerente a todos os seres humanos e se manifesta desde a infância. No entanto, para ser desenvolvida e potencializada, necessita de um contínuo processo de educação dos sentidos, de formação, informação e aperfeiçoamento. Não por acaso, a formação foi a principal demanda apontada na II Conferência Nacional de Cultura, seja voltada para o corpo técnico de seus órgãos gestores, seja para o conjunto dos trabaIhadores da Cultura, tanto para o estímulo e aperfeiçoamento no campo criativo, estético, quanto institucional. Nesse contexto, investir conjuntamente em Cultura e Educação é estratégico, e para isso, é necessário criar instâncias de coordenação entre as políticas culturais e educacionais e estimular a interação entre as expressões da Cultura e o sistema educativo. As políticas culturais e educacionais podem construir uma agenda comum e colaborativa que qualifique a Educação Artística, implante a Educação Patrimonial e contribua para o incentivo ao Livro e à Leitura.

Tão imprescindível quanto reatar o vínculo entre Cultura e Educação, é integrar as políticas Culturais e de Comunicação, muito em função do papel dos meios de comunicação de massas de produtor e difusor de Cultura. No Brasil, sobretudo, a televisão e o rádio são os equipamentos de produção e distribuição dos bens simbólicos mais disseminados e ocupam um papel relevante na vida cultural. Mata Machado (2012) menciona que, na esfera da Comunicação, um dos principais desafios é garantir o cumprimento dos artigos da Constituição de 88, no que se refere ao princípio da regionalização da produção cultural, artística e jornalística, bem como, a prioridade à finalidade educativa, à promoção da Cultura nacional, regional e a produção independente (art. 221). Cabe, também, 
regulamentar o princípio da complementaridade dos sistemas privado, público e estatal de rádio e televisão (art. 223).

O monopólio dos meios de comunicação representa uma ameaça à democracia e aos direitos humanos, afetando diretamente os requisitos básicos da produção, difusão e acesso às informações para o exercício das liberdades civis, políticas, econômicas, sociais e culturais. As TVs e rádios públicas precisam estar independentes do mercado e dos governos, voltadas para a autonomia de seus ouvintes e telespectadores, dentro de uma programação que não esteja padronizada em um único modelo, homogeneizante e hegemônico, mas que espelhe as diferentes realidades, experimentações de linguagens, debate de ideias. Para isso, necessita definir um marco regulatório descentralizado e democrático das concessões públicas, na adoção de um modelo aberto à participação de produtores independentes e na criação de um sistema de financiamento que articule o compromisso de Municípios, Estados e União, conjugando programações para diferentes meios, como a telefonia celular e a internet, e espaços educativo-culturais, como escolas, universidades, centros culturais, sindicatos e associações comunitárias.

De acordo ainda com o Documento-base da Conferência Nacional, a Cultura pode estar integrada também às políticas de Saúde, seja na criação de ambientes lúdicos para o tratamento e socialização de doentes, seja no desenvolvimento de terapias baseadas nas artes - música, dança, artes visuais - adequadas à cura de sofrimentos mentais e outras enfermidades, seja na prevenção de doenças, por estimular os sentidos e instaurar um ambiente saudável impactando diretamente em todas as dimensões da vida humana. Da mesma forma, as políticas de Cultura e Segurança Pública precisam estar interli- gadas, não somente porque a capacidade de encantar, humanizar e reconstituir possibilidades de vida da Cultura reduzem ou previnem a violência, mas pela possibilidade de instaurar processos de autonomia e emancipação da sociedade. Requer uma política de ações e programas sociais e culturais estruturantes, de forma a garantir a valorização, a autoralidade e o pertencimento dos agentes culturais, assim como, de formação e profissionalização das polícias que garanta uma efetiva segurança pública na cidade.

Muitos dos desafios que entraram no Plano Nacional de Cultura, resultado da ampla escuta que fez o Ministério da Cultura em conferências pelo país, envolvem áreas transversais como Ciência e Tecnologia, quando sinaliza para o reconhecimento da inovação científica e tecnológica como valor estratégico para a Cultura. E a ampliação dos meios digitais de expressão e acesso à Cultura e ao conhecimento, incorporando a diversidade cultural do país, com seus múltiplos conhecimentos e técnicas e articulação com os programas de inclusão digital, uma vez que os novos aparatos tecnológicos influenciam as dinâmicas de expressão, fruição e consumo cultural. Da mesma forma, o desafio da área de Turismo, para desenvolver o turismo cultural sustentável e não predatório, através da valorização da diversidade.

O Plano Municipal de Cultura terá, portanto, como desafio traçar políticas e estratégias integrais para a transformação cultural e cívica da cidade, gerar ações para a defesa da vida como valor supremo; acrescentar oportunidades da juventude; promover espaços de reconhecimento da diversidade; fomentar a promoção turística da cidade; conformar redes comunitárias para ascender a projetos produtivos, urdir as relações cotidianas que expressam as tradições e os novos cidadãos e promover pactos sociais de reconhecimento e valorização da Cultura da cidade. 
Em respeito ao significado da cidade do Rio, daquilo que representa e daquilo que ainda pode ser, daquilo que anseia e almeja ser, como fazer um plano que espelhe as carências e as potências dessa cidade? Como garantir o pleno exercício dos direitos culturais dos atores desse processo? Como corrigir desigualdades e concentrações? Como democratizar o acesso e a participação?

Conforme vimos, essas questões devem estar nas bases de implantação de uma política cultural que dê condições e fomento para deixar florescer a cidade e seus cidadãos, em tudo o que são e o que ainda podem ser, dentro de um conceito de Cultura cidadã, desde o qual construir cidade é construir cidadania para a cidade. No entanto, percebe-se uma série de entraves e descontinuidades ocorridas nas mudanças de gestão, cujos impactos interferem na implantação do Plano e do Sistema Municipal de Cultura como um todo. Nessa trajetória, identificamos a necessidade de se garantir a continuidade desse processo de construção de políticas públicas, a partir dessa escuta e do diagnóstico registrado, de forma a corrigir as fragilidades, as distorções e as desigualdades, apontadas no setor cultural, reforçando suas vocações e potencialidades. O grande desafio continua sendo esse: ir além de uma política de gestão, para fazer-se uma Política de Estado para a Cultura.

\section{Referências}

CALABRE, Lia (org.). Oficinas do Sistema Nacional de Cultura. Brasília. Ministério da Cultura, 2006.

CALABRE, Lia (org.). Políticas Culturais: reflexões sobre gestão, processos participativos e desenvolvimento. SP: Itaú Cultural; RJ: Fundação Casa de Rui Barbosa, 2009.
CALVINO, Ítalo. As Cidades Invisíveis. São Paulo: Cia das Letras, 2006.

CARTILHA de Orientações sobre o Sistema Nacional de Cultura para os Municípios. Brasília: Ministério da Cultura, 2010.

FERRARA, Lucrecia D`Alessio. Ver a cidade: cidade, imagem e leitura. São Paulo: Ed. da Unicamp, 1992.

GARCÍA CANCLINI, Néstor. Políticas Culturales en América Latina. México: Grijalbo, 1987.

GIL, Herman Montoya: La construcción de una política cultural local en Medellín. Disponível em: www.medellincultura.gov.co/plan_de_desarrollo_cultural_de_Medellín_2011-2020) pdf). Acesso em: 08/04/2012.

MACHADO, Bernardo Novais da Mata. Documento base da I Conferência Nacional de Cultura, elaborado com a gestão do Ministério da Cultura. Disponível em: blogs. cultura.gov.br/snc/tag/planonacional-de-cultura). Acesso em: 07/02/2012.

PLAN de Desarrollo Cultural de Medellín 2011 2020. Medellín, una ciudad que se piensa y se construye desde la cultura. Medellín: Imprenta Universidad de Antioquia, 2011. Disponível em: https://issuu.com/cultudocs/docs/plan_de_desarrollo_cultural_de_medellin_2011-2020). A Acesso em: $13 / 03 / 2012$.

PLAN Departamental de Cultura 2006-2020 - Antioquia em suas diversas Vozes. Medellin: Universidad de Antioquia, 2009. Disponível em: https:// www.culturantioquia.gov.co/images/documentos/ estrategicos/Plan-Departamental-de-Cultura-Antioquia-Diversas-Voces-2006-2020.pdf).

PLANO Estratégico da Cidade do Rio de Janeiro - 2013-2016. Disponível em: http://www.rio.rj.gov. $\mathrm{br} / \mathrm{dlstatic/10112/2116763/4104304/planejamen-}$ to_estrategico_1316.pdf).

RODRIGUES, Luiz Augusto F. Gestão cultural e seus eixos temáticos. In: CURVELLO, M. A. [et al] (orgs.). Políticas públicas de cultura do Estado do Rio de Janeiro: 2007-2008. Rio de Janeiro: Uerj/ Decult, 2009. p. 76-93.

RUBIM, Albino. Políticas culturais: entre o possível e o impossível. In: NUSSBAUMER, Gisele Marchiori (org.). Teorias e políticas da cultura: visões multidisciplinares. Salvador: EDUFBA, 2005. p.139-158. 